\title{
Studies on chemical composition and feeding value in forage crops
}

\author{
XIII. Effect of the stage of maturity in spring and the time of repeated \\ harvest in regrowth period on the chemical composition and feeding \\ value of Ladino clover (Trifolium repens latum) grown \\ in the warmer Setouchi district in Japan
}

\author{
Takashi Mıaki \\ (Faculty of Agriculture, Okayama University) \\ (Received for Publication on March 19, 1969)
}

Ladino clover is one of the promising perennial leguminous forages as soiling and pasture crops in the warmer Setouchi district of Japan. There is, however, little information available concerning its feeding value. The objectives of this study were: (1) to determine the variation in feeding value of Ladino clover with advancing maturity in spring (the first growth period) and (2) to compare the feeding value among the first to fourth crops harvested at approximately the early bloom stage of growth.

\section{Materials and Methods}

The data on climatic conditions in the growing seasons of 1966 and 1967 are shown in Table 1. From this Table, it can be seen that the average temperature in June to mid-September of 1967 was slightly higher than that of the corresponding period of 1966 . The total amount of precipitation was $411.6 \mathrm{~mm}$ during the period from June to September of 1967 which was $44 \%$ less than the previous year $(736.7 \mathrm{~mm})$. Such climatic conditions in 1967 were unfavorable to the growth of the forage under study when compared with those in 1966.

The experiments were carried out at the experimental field of the Faculty of Agriculture, Okayama University in both 1966 and 1967.

Experiment in 1966. Oregon Ladino clover (Trifolium repens latum) was broadcasted at a rate of $500 \mathrm{~g}$ per $10 \mathrm{a}$ in the fall of 1965 . Prior to seeding $4 \mathrm{~kg}$ of $\mathrm{N}$ as ammonium sulfate, $4.8 \mathrm{~kg}$ of $\mathrm{P}_{2} \mathrm{O}_{5}$ as superphosphate, $5 \mathrm{~kg}$ of $\mathrm{K}_{2} \mathrm{O}$ as muriate of potash and $30 \mathrm{~kg}$ of $\mathrm{Ca}(\mathrm{OH})_{2}$ per $10 \mathrm{a}$, respectively, were applied to the field. In February of 1966 , the clover stand was fertilized with $2 \mathrm{~kg}$ of $\mathrm{N}, 3.2 \mathrm{~kg}$ of $\mathrm{P}_{2} \mathrm{O}_{5}$ and $6.5 \mathrm{~kg}$ of $\mathrm{K}_{2} \mathrm{O}$ per $10 \mathrm{a}$, respectively, as ammonium sulfate, superphosphate and muriate of potash. The clover was harvested at approximately the early bloom stage as shown in Table 2. The forages harvested at four cutting dates were assigned to two rabbits (about $2500 \mathrm{~g}$ of body weight) for each of the four consecutive trials starting in May of 1966. The rabbits were fed $600 \mathrm{~g}$ of fresh forage cut in small pieces (about $2 \mathrm{~cm}$ in length) per day in two equal portions. Water was available all day. Each digestion trial consisted of a 5-day preliminary period followed by a 5-day collection period in which total fecal collection was made. The animals were kept in individual metabolic cages. Feces were removed each day and dried at about $70^{\circ} \mathrm{C}$ in a forced air dryer for $7-8 \mathrm{hr}$. Feces collected for five days were then mixed thoroughly and ground finely in a hammer mill. Two hundred grams 
MLAKI

Table 1. Outline of climatic condition for growing season of 1966 and 1967a

\begin{tabular}{|c|c|c|c|c|c|c|c|c|c|}
\hline \multirow{2}{*}{ Year } & \multirow{2}{*}{ Month } & \multicolumn{4}{|c|}{ Precipitation (mm) } & \multicolumn{3}{|c|}{ Temperature $\left({ }^{\circ} \mathrm{C}\right)$} & \multirow{2}{*}{$\int_{\text {(hour) }}^{\text {Sunshineb }}$} \\
\hline & & $\begin{array}{c}\text { l st } \\
\text { decade }\end{array}$ & $\begin{array}{c}2 \text { nd } \\
\text { decade }\end{array}$ & $\begin{array}{c}3 \text { rd } \\
\text { decade }\end{array}$ & Total & $\begin{array}{c}\text { Mean } \\
\text { maximum }\end{array}$ & $\begin{array}{c}\text { Mean } \\
\text { minimum }\end{array}$ & Mean & \\
\hline \multirow{8}{*}{1966} & April & 43.5 & 20.4 & 44.3 & 108.2 & 18.3 & 7.5 & 12.8 & 176.4 \\
\hline & May & 61.0 & 16.3 & 139.8 & 217.1 & 22.6 & 10.5 & 16.5 & 221.7 \\
\hline & June & 133.4 & 46.0 & 45.1 & 224.5 & 25.5 & 17.2 & 20.9 & 168.5 \\
\hline & July & 86.3 & 37.5 & 16.2 & 140.0 & 29.1 & 19.9 & 24.1 & 198.0 \\
\hline & August & 46.6 & 23.8 & 5.2 & 75.6 & 32.1 & 24.0 & 27.6 & 215.4 \\
\hline & September & 40.7 & 128.1 & 127.8 & 296.6 & 27.4 & 18.1 & 22.3 & 173.5 \\
\hline & October & 5.6 & 34.8 & 22.9 & 62.3 & 22.4 & 10.9 & 16.2 & 170.0 \\
\hline & November & 3.0 & 32.3 & 18.6 & 53.9 & 16.4 & 4.5 & 10.0 & 160.9 \\
\hline \multirow{8}{*}{1967} & April & 97.9 & 104.2 & 27.8 & 229.9 & 18.8 & 9.1 & 13.5 & 150.8 \\
\hline & May & 81.9 & 0.0 & 61.8 & 143.7 & 25.7 & 12.7 & 18.7 & 254.1 \\
\hline & June & 12.2 & 0.0 & 75.7 & 87.9 & 28.4 & 17.3 & 22.4 & 226.5 \\
\hline & July & 205.4 & 69.5 & 0.0 & 274.9 & 30.5 & 22.9 & 26.2 & 191.5 \\
\hline & August & 2.4 & 3.7 & 20.5 & 26.6 & 33.8 & 23.6 & 28.0 & 248.5 \\
\hline & September & 0.4 & 19.5 & 2.3 & 22.2 & 29.4 & 18.9 & 23.5 & 197.3 \\
\hline & October & 27.6 & 19.0 & 83.1 & 129.7 & 22.1 & 11.4 & 16.1 & 169.6 \\
\hline & November & 12.2 & 37.1 & 12.4 & 61.7 & 16.8 & 6.2 & 10.9 & 130.7 \\
\hline
\end{tabular}

a) Cited from the records of the Okayama Meteorologic Observatory, some $300 \mathrm{~m}$ distant from the experimental field.

b) Recorded by Jordan's recorder.

of forages were collected daily from the same forage fed to the animals during the collection period and then were treated by the same manner used in the case of the feces. The chemical compositions of the feces and forage samples for determination of digestibilities of dry matter, crude protein, crude fat, NFE and crude fiber were analysed by the conventional method ${ }^{1}$. Crude lignin, calcium and phosphorus were analysed according to the methods used in the previous report ${ }^{4}$. Samples for leaf-stem separations were taken from the forage harvested on the third day of the collection period. Plant samples were separated into leaf, pedicel and flower fractions. The percentage of each was calculated from air-dry weight of the fractions. Plant height is shown as the average of 20 plants at the time of leaf-stem separation.

Experiment in 1967. In mid-February of 1967 the same area used in Experiment in 1966 was fertilized with $60 \mathrm{~kg}$ per 10 a of 7-11-7 (N-P.K) mixed fertilizer. As indicated in Table 2, the forage was harvested at the early vegetative, late vegetative, bud and early bloom stages of the first growth in spring and the second to fourth crops in the regrowth period were harvested at approximately the same as the early bloom stage in the first growth. Seven digestion trials were conducted from April to November of 1967 with the same feeding, collection, sampling and analytical procedures employed in Experiment in 1966.

\section{Results and Discussion}

Table 2 shows the fractions of the plant organs of the forage when harvested for the digestion trial. In spring of 1967 , leaf content decreased sharply with advance in the growth stage from $71 \%$ at the early vegetative to $36 \%$ at the early bloom stage. Leaf content for each of the first to fourth crops harvested at approximately the early bloom stage was larger 
Feeding value of Ladino clover

Table 2. Morphorogical character and yield of Ladino clover when harvested for digestion trial

\begin{tabular}{|c|c|c|c|c|c|c|c|c|c|}
\hline \multirow{2}{*}{ Year } & \multirow{2}{*}{$\begin{array}{l}\text { Stage of } \\
\text { maturity }\end{array}$} & \multirow{2}{*}{$\begin{array}{l}\text { Date of } \\
\text { digestion } \\
\text { trial }\end{array}$} & \multirow{2}{*}{$\begin{array}{l}\text { Plant } \\
\text { height }\end{array}$} & \multicolumn{3}{|c|}{ Fraction of organa) } & \multicolumn{3}{|c|}{ Yield per $10 \mathrm{a}$} \\
\hline & & & & Leaf & Pedicle & Flower & $\mathrm{DM}^{\mathrm{b}}$ & DCP & TDN \\
\hline \multirow{4}{*}{1966} & 1 st crop & May $18-22$ & $\begin{array}{c}\mathrm{cm} \\
43.4\end{array}$ & 33 & $\begin{array}{c}\% \\
66\end{array}$ & $1^{\%}$ & $\begin{array}{r}\mathrm{kg} \\
568\end{array}$ & $\frac{\mathrm{kg}}{121}$ & $\begin{array}{l}\mathrm{kg} \\
354\end{array}$ \\
\hline & 2 nd crop & June $20-24$ & 35.6 & 41 & 57 & 2 & 184 & 42 & 130 \\
\hline & 3 rd crop & July $23-27$ & 44.0 & 44 & 54 & 2 & 216 & 43 & 141 \\
\hline & 4 th crop & Oct. $20-24$ & 39.9 & 48 & 52 & 0 & 201 & 47 & 141 \\
\hline \multirow{7}{*}{1967} & $\begin{array}{l}\text { Early } \\
\text { vegetative }\end{array}$ & April 2- 6 & 18.5 & 71 & 29 & 0 & 97 & 30 & 71 \\
\hline & $\begin{array}{l}\text { Late } \\
\text { vegetative }\end{array}$ & April $_{24-28}$ & 34.6 & 48 & 52 & 0 & 141 & 36 & 102 \\
\hline & Bud & May $10-14$ & 52.0 & 40 & 60 & 0 & 197 & 46 & 147 \\
\hline & Early bloom & May $22-26$ & 54.2 & 36 & 63 & 1 & 216 & 42 & 157 \\
\hline & 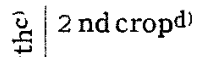 & June $18-22$ & 32.6 & 48 & 49 & 3 & 138 & 26 & 92 \\
\hline & 3 rd crop & July $13-17$ & 31.2 & 49 & 47 & 4 & 81 & 21 & 60 \\
\hline & | 4 th crop & Nov. $15-19$ & 24.2 & 61 & 39 & 0 & 77 & 19 & 61 \\
\hline
\end{tabular}

a) Expressed on oven-dry basis.

b) Dry matter.

c) Harvested at the early bloom stage except 4 th crop.

d) The first cutting was made at the early bloom stage.

in 1967 than in 1966, particularly for the fourth crop. In general, the leaf content increased in both years with increase in the frequency of repeated harvest in the regrowth period.

The chemical compositions of the forages are shown in Table 3. In Experiment of 1967, crude protein content decreased with advancing maturity in spring from $35.8 \%$ at the early vegetative to $23.5 \%$ at the early bloom stage and crude fat content decreased slightly, whereas crude fiber and crude lignin contents increased, especially at the early bloom stage the former increased to almost two times of that at the early vegetative stage. Phosphorus content decreased slightly as the plant developed, but calcium content decreased at the initial growth stages and increased slightly at the early bloom stage. KamEtaKA and HARUYAMA $^{3)}$ have reported that the calcium content of wild white clover in bloom increases significantly. Such variations in chemical compositions may be due to changes in the fractions of plant organ with advancing maturity. As shown in Table 4, leaves contain more crude protein, calcium and phosphorus, and less crude fiber than pedicels. IтоH et al. ${ }^{2}$ ) have also reported that the calcium content in leaf of Ladino clover is higher than the value of pedicel. Moreover, the contents of crude protein and crude fiber in the leaves are almost unchanged with advancing maturity, whereas in the pedicels crude protein content decreases and crude fiber content increases. Therefore, it may be considered that an increase in the pedicel fraction with maturity was accompanied with lower crude protein and higher crude fiber in the whole plant.

The chemical compositions for the first to fourth crops harvested at approximately the early bloom stage in both years are given in Table 3 . There is almost no difference in the average content of each component other than crude lignin in the first to fourth crops of both years but the average content of crude lignin was higher in 1966 than 1967. It appears that the higher content of crude lignin in 1966 is associated with lower leaf content of the forages in the corresponding year. While the fourth crop in 1967 had a higher leaf content than the 
MIAKI

Table 3. Chemical composition of Ladino clovera)

\begin{tabular}{|c|c|c|c|c|c|c|c|c|c|c|}
\hline \multirow{2}{*}{ Year } & \multirow{2}{*}{$\begin{array}{l}\text { Stage of } \\
\text { Maturity }\end{array}$} & \multirow{2}{*}{ Moisture } & \multirow{2}{*}{$\begin{array}{l}\text { Crude } \\
\text { protein }\end{array}$} & \multirow{2}{*}{$\underset{\text { fat }}{\text { Crude }}$} & \multirow{2}{*}{ NFE } & \multirow{2}{*}{$\begin{array}{l}\text { Crude } \\
\text { fiber }\end{array}$} & \multirow{2}{*}{$\begin{array}{l}\text { Crude } \\
\text { ash }\end{array}$} & \multirow{2}{*}{$\begin{array}{l}\text { Crude } \\
\text { lignin }\end{array}$} & \multicolumn{2}{|c|}{ Mineral } \\
\hline & & & & & & & & & $\mathrm{Ca}$ & $\mathbf{P}$ \\
\hline \multirow{6}{*}{1966} & 1 st crop & $\begin{array}{l}\% \% \\
89.6\end{array}$ & 26.3 & $4 \%$ & 39.1 & 18.5 & 12.0 & $11.7 \%$ & $\begin{array}{l}1.65 \\
1.65\end{array}$ & 0.46 \\
\hline & 2 nd crop & 88.0 & 26.9 & 4.0 & 42.3 & 15.2 & 11.6 & 8.5 & 1.68 & 0.43 \\
\hline & 3 rd crop & 88.6 & 25.5 & 4.1 & 43.0 & 16.5 & 10.9 & 11.9 & 1.87 & 0.40 \\
\hline & 4 th crop & 87.3 & 29.3 & 4.4 & 41.5 & 15.2 & 9.6 & 7.9 & 1.89 & 0.35 \\
\hline & Mean & 88.4 & 27.0 & 4.2 & 41.4 & 16.4 & 11.0 & 10.0 & 1.77 & 0.41 \\
\hline & S.D.b) & 0.8 & 1.4 & 0.1 & 3.1 & 1.3 & 0.9 & 1.8 & 0.11 & 0.04 \\
\hline \multirow{11}{*}{1967} & $\begin{array}{l}\text { Early } \\
\text { vegetative }\end{array}$ & 91.4 & 35.8 & 4.2 & 35.6 & 9.0 & 15.4 & 5.7 & 1.78 & 0.70 \\
\hline & $\begin{array}{l}\text { Late } \\
\quad \text { vegetative }\end{array}$ & 89.7 & 29.5 & 3.2 & 42.0 & 13.7 & 13.4 & 6.1 & 1.54 & 0.63 \\
\hline & Bud & 91.3 & 27.2 & 3.3 & 39.6 & 17.4 & 12.5 & 8.1 & 1.43 & 0.53 \\
\hline & Early bloom & 88.3 & 23.5 & 4.0 & 43.0 & 17.6 & 11.9 & 8.8 & 1.54 & 0.50 \\
\hline & $\vec{F} \mid 2$ nd crop & 79.9 & 23.3 & 4.3 & 45.0 & 16.2 & 11.2 & 7.8 & 1.87 & 0.36 \\
\hline & 옹. 3 rd crop & 89.2 & 30.3 & 3.9 & 38.8 & 15.7 & 11.3 & 6.3 & 1.51 & 0.52 \\
\hline & $\stackrel{\stackrel{\Delta}{\sim}}{4} 4$ th crop & 85.7 & 28.0 & 5.4 & 43.1 & 12.0 & 11.5 & 5.7 & 1.73 & 0.42 \\
\hline & Meanc' & 85.8 & 26.3 & 4.4 & 42.4 & 15.4 & 11.5 & 7.2 & 1.66 & 0.44 \\
\hline & S.D.b! & 3.6 & 3.0 & 0.6 & 3.1 & 2.1 & 0.3 & 1.2 & 0.18 & 0.06 \\
\hline & Meanc ${ }^{d}$ ) & 87.1 & 26.6 & 4.3 & 41.9 & 15.9 & 11.3 & 8.6 & 1.71 & 0.42 \\
\hline & S.D.b) & 2.9 & 2.4 & 0.4 & 2.4 & 1.8 & 0.7 & 1.1 & 0.16 & 0.06 \\
\hline
\end{tabular}

a) Expressed as a percentage of the dry matter except moisture.

b) Standard deviation.

c) Not include the early vegetative to bud stages.

d) Average of two years.

Table 4. Chemical composition of two plant fractions of Ladino clover

\begin{tabular}{|c|c|c|c|c|c|c|c|c|c|c|}
\hline \multirow{3}{*}{$\begin{array}{c}\text { Stage } \\
\text { of } \\
\text { Maturity }\end{array}$} & \multicolumn{5}{|c|}{ Leaf fraction } & \multicolumn{5}{|c|}{ Pedicel fraction } \\
\hline & \multirow{2}{*}{$\begin{array}{l}\text { Crude } \\
\text { protein }\end{array}$} & \multirow{2}{*}{$\begin{array}{l}\text { Crude } \\
\text { fiber }\end{array}$} & \multirow{2}{*}{$\begin{array}{l}\text { Crude } \\
\text { ash }\end{array}$} & \multicolumn{2}{|c|}{ Mineral } & \multirow{2}{*}{$\begin{array}{l}\text { Crude } \\
\text { protein }\end{array}$} & \multirow{2}{*}{$\begin{array}{l}\text { Crude } \\
\text { fiber }\end{array}$} & \multirow{2}{*}{$\begin{array}{l}\text { Crude } \\
\text { ash }\end{array}$} & \multicolumn{2}{|c|}{ Mineral } \\
\hline & & & & $\mathrm{Ca}$ & $\mathrm{P}$ & & & & $\mathrm{Ca}$ & $P$ \\
\hline $\begin{array}{l}\text { Early } \\
\text { vegetative }\end{array}$ & $\begin{array}{c}\% \\
37.6\end{array}$ & $7 . \%$ & $11.2^{\%}$ & 1.80 & $0.70^{\%}$ & 23.4 & 14.5 & 14.4 & $1.70^{\%}$ & $\begin{array}{l}\% \\
0.59\end{array}$ \\
\hline $\begin{array}{l}\text { Late } \\
\text { vegetative }\end{array}$ & 40.0 & 8.5 & 10.8 & 1.63 & 0.68 & 20.9 & 13. 7 & 13.8 & 1.50 & 0.58 \\
\hline Bud & 38.7 & 8.9 & 9.8 & 1.50 & 0.58 & 19.4 & 21.5 & 13.9 & 1.40 & 0.50 \\
\hline $\begin{array}{l}\text { Early } \\
\quad \text { bloom }\end{array}$ & 38.8 & 9.7 & 10.0 & 1.70 & 0.50 & 14.8 & 23.4 & 12.4 & 1.51 & 0.40 \\
\hline 击 2 nd crop & 33.4 & 9.0 & 9.8 & 1.71 & 0.38 & 15.7 & 21.5 & 11.9 & 1.60 & 0.30 \\
\hline 吾 $3 \mathrm{rd}$ crop & 37.2 & 10.2 & 8.4 & 1.62 & 0.49 & 21.4 & 21.7 & 11.4 & 1.52 & 0.48 \\
\hline $\begin{array}{ll}0 & 0 \\
0 & 4\end{array}$ th crop & 35.4 & 7.4 & 9.7 & 1.86 & 0.45 & 13.1 & 13.0 & 11.9 & 1.56 & 0.40 \\
\hline Meana) & 37.4 & 8.8 & 9.9 & 1.72 & 0.54 & 19.4 & 18.5 & 12.8 & 1.54 & 0.46 \\
\hline S.D.b) & 2.1 & 0.9 & 0.8 & 0.13 & 0.11 & 3.6 & 4.2 & 1.1 & 0.26 & 0.03 \\
\hline
\end{tabular}

a) Average of the 1 st. 2 nd, 3 rd and 4 th crops harvested at approximately the early bloom stage.

b) Standard deviation.

Values expressed as a percentage on a dry matter basis.

third crop, its crude protein content was lower. This may be due to the lower content of crude protein of the fourth crop in both leaves and pedicels when compared with that of the third crop as shown in Table 4. 
As the frequency of repeated harvest in the regrowth period increases, a sharp decrease is indicated in the contents of crude fiber and lignin in both years, but there was no distinct tendency of either increase or decrease in the other feed constituents.

When the chemical composition was compared with the alfalfa of the previous report ${ }^{41}$, the Ladino clover was richer in crude protein, crude ash, calcium and phosphorus but the content of crude fiber was lower through the first growth and regrowth periods.

The apparent digestibility of each component of the forage is summarized in Table 5. Almost no difference was observed in the digestibilities of dry matter, organic matter, crude fat and NFE among four stages in spring of 1967 but those of crude protein and crude fiber remained almost constant to the bud stage and then declined about four and five percents, respectively, at the early bloom stage.

The average digestibility of each component, especially crude fat and crude fiber, for the first to fourth crops harvested at approximately the early bloom stage was much higher in 1967 than in 1966. These results may be due to the fact that the forages harvested in 1967 contained an average of $2.8 \%$ less crude lignin than those harvested in 1966 . The reason for this remarkable defference in the crude fat digestibility between both years is not known.

During the first growth and regrowth periods in both years, the forages were more digestible with respect to all feed constituents than the alfalfa cited above.

Table 5. Apparent digestibility and digestible nutrients of Ladino clover

\begin{tabular}{|c|c|c|c|c|c|c|c|c|c|}
\hline Year & Stage of Maturity & $\begin{array}{c}\text { Dry } \\
\text { matter }\end{array}$ & $\begin{array}{c}\text { Organic } \\
\text { matter }\end{array}$ & $\begin{array}{l}\text { Crude } \\
\text { protein }\end{array}$ & $\begin{array}{c}\text { Crude } \\
\text { fat }\end{array}$ & NFE & $\begin{array}{l}\text { Crude } \\
\text { fiber }\end{array}$ & DCPal & TDNa! \\
\hline \multirow{6}{*}{1966} & \multirow{6}{*}{$\begin{array}{l}1 \text { st crop } \\
2 \text { nd crop } \\
3 \text { rd crop } \\
4 \text { th crop } \\
\text { Mean } \\
\text { S.D.b) }\end{array}$} & $\begin{array}{l}\% \\
68.7\end{array}$ & $\begin{array}{c}\% \\
68.6\end{array}$ & $\begin{array}{l}\% \% \\
78.5\end{array}$ & $38.7^{\%}$ & $75.1^{\%}$ & $\begin{array}{l}\% \% \\
47.5\end{array}$ & $\begin{array}{l}\% \% \\
20.6\end{array}$ & $62.3^{\%}$ \\
\hline & & 72.1 & 73.4 & 85.1 & 41.9 & 86.1 & 48.8 & 22.9 & 70.5 \\
\hline & & 71.1 & 72.1 & 79.0 & 44.0 & 80.1 & 47.8 & 20.1 & 65.5 \\
\hline & & 76.1 & 76.4 & 80.3 & 32.8 & 87.0 & 48.7 & 23.5 & 70.2 \\
\hline & & 72.0 & 72.6 & 80.7 & 39.3 & 82.1 & 48.2 & 21.8 & 67.1 \\
\hline & & 2.7 & 2.8 & 2.6 & 4.2 & 4.8 & 0.6 & 1.3 & 3.5 \\
\hline \multirow{9}{*}{1967} & \multirow{4}{*}{$\begin{array}{l}\text { Early vegetati } \\
\text { Late vegetative } \\
\text { Bud } \\
\text { Early bloom }\end{array}$} & 80.7 & 82.7 & 86.6 & 61.6 & 84.9 & 67.8 & 31.0 & 73.1 \\
\hline & & 80.4 & 81.7 & 87.2 & 56.6 & 83.7 & 69.6 & 25.7 & 72.8 \\
\hline & & 82.4 & 83.6 & 86.4 & 58.8 & 89.4 & 67.7 & 23.5 & 74.8 \\
\hline & & 80.3 & 80.4 & 82.7 & 61.8 & 85.4 & 62.2 & 19.5 & 72.6 \\
\hline & \multirow{4}{*}{\begin{tabular}{l|l}
$\underset{5}{5}$ & 2 nd crop \\
$\stackrel{5}{5}$ & 3 rd crop \\
$\underset{0}{0}$ & 4 th crop \\
Meanc
\end{tabular}} & 73.8 & 73.6 & 79.8 & 52.5 & 77.4 & 49.2 & 18.6 & 66.4 \\
\hline & & 79.5 & 80.2 & 85.5 & 60.0 & 85.9 & 60.7 & 25.9 & 74.0 \\
\hline & & 85.7 & 86.5 & 89.1 & 75.2 & 85.2 & 75.0 & 25.0 & 79.7 \\
\hline & & 79.8 & 80.2 & 84.3 & 62.4 & 83.5 & 61.8 & 22.2 & 73.2 \\
\hline & S.D.b) & 3.1 & 4.5 & 3.4 & 8.2 & 3.5 & 9.1 & 3.2 & 3.1 \\
\hline \multicolumn{2}{|r|}{ Meanc,d) } & 75.8 & 76.4 & 82.5 & 50.9 & 82.5 & 55.0 & 22.0 & 70.1 \\
\hline \multicolumn{2}{|r|}{ S.D.b) } & 4.7 & 5.3 & 3.5 & 13.2 & 4.3 & 9.4 & 2.5 & 4.3 \\
\hline
\end{tabular}

a) Expressed as a percentage on a dry matter basis.

b) Standard deviation.

c) Not include the early vegetative to bud stages.

d) Average of two years.

The feeding values of the forages expressed as DCP and TDN are presented in Table 5 . It was found from Experiment in 1967 that DCP content declined sharply with advancing maturity from $31.0 \%$ at the early vegetative to $19.5 \%$ at the early bloom stage. A sharp decline of 
DCP content from the vegetative to the bud stage undoubtedly is due to a decrease in crude protein content with advancing maturity because the digestibility of corresponding component remained almost unchanged to the bud stage. The rate of decline in DCP was about $0.26 \%$ per day as compared with about $0.7 \%$ for the alfalfa cited above. There was no appreciable difference in TDN content among the forages harvested at the four stages in spring of 1967.

The average DCP contents of the first to fourth crops harvested at approximately the early bloom stage were $21.8 \%$ and $22.2 \%$, respectively, in 1966 and in 1967. The average TDN contents of the corresponding crops were $67.1 \%$ in 1966 and $73.2 \%$ in 1967 . This remarkable difference in TDN may be due to the difference in the digestibilities of feed constituents, particularly those of crude fat and crude fiber, since there are no appreciable difference in the average contents of chemical compositions between both years as shown in Table 3.

In the comparison of DCP and TDN contents among the first to fourth crops harvested at approximately the early bloom stage, there was no large difference in DCP content in 1966, but in 1967 the third and fourth crops showed a much higher content of DCP as compared with the others.

Dry matter and nutrient yields per $10 \mathrm{a}$ are give in Table 2. Dry matter yield per $10 \mathrm{a}$ in spring of 1967 increased rapidly from $97 \mathrm{~kg}$ at the early vegetative to $216 \mathrm{~kg}$ at the early bloom stage. Each yield of the first to fourth crops harvested at approximately the early bloom stage in 1967 was extremely low in comparison with those in 1966. This decline in dry matter yield in 1967 is mainly due to reduction in density of the sward with drought as well as with the lapse of the year. Yields of DCP and TDN also increased with advancing maturity and the maximum yield of DCP in spring was attained in the bud stage and that of TDN in the early bloom stage. The growth stages of maximum yields of both digestible nutrients were the same as the alfalfa cited above.

The yields of DCP and TDN for each of the second to the fourth crops were markedly inferior to those of the first crop at the early bloom stage.

Relationships between leaf content and chemical constituents, such as crude protein and crude lignin, of the forages harvested in both years and DCP and TDN contents are shown in

Table 6. Correlation and regression of leaf content and chemical constituents with digestible nutrients of Ladino clover

\begin{tabular}{|c|c|c|c|c|}
\hline $\mathrm{x}$ & $\mathrm{Y}$ & $\mathbf{r}$ & Regression equation & $\begin{array}{l}\text { Standard error } \\
\text { of the estimate }\end{array}$ \\
\hline Leaf content & $\begin{array}{l}\text { Crude protein } \\
\text { Crude fiber } \\
\text { DCP } \\
\text { TDN }\end{array}$ & $\begin{array}{c}0.741^{* *} \\
-0.942^{* * *} \\
0.776^{* *} \\
0.488\end{array}$ & 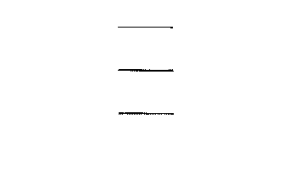 & \\
\hline Crude protein & $\begin{array}{l}\text { DCP } \\
\text { TDN }\end{array}$ & $\begin{array}{l}0.967^{* * * *} \\
0.424\end{array}$ & $Y=-4.62+1.003 X$ & 0.87 \\
\hline Crude lignin & $\begin{array}{l}\text { DCP } \\
\text { TDN }\end{array}$ & $\begin{array}{l}-0.716^{* *} \\
-0.786^{* *}\end{array}$ & $X=83.25-1.599 X$ & 2.53 \\
\hline Crude fiber & $\begin{array}{l}\text { DCP } \\
\text { TDN }\end{array}$ & $\begin{array}{l}-0.830^{* * *} \\
-0.448\end{array}$ & - & \\
\hline
\end{tabular}

Chemical constituents and digestible nutrients expressed on a dry matter basis.

***(**) Statistically significant at the $0.1 \%(1 \%)$ level.

- These equations were not computed. 
Table 6. There was a significant positive correlation between the leaf content and the contents of crude protein and DCP and a significant negative correlation between the leaf content and the crude fiber content, and their correlation coefficients were $0.741 \quad(P<0.01), 0.776(P<0.01)$ and $-0.942(P<0.001)$, respectively. The crude protein content was highly correlated with DCP content, its correlation coefficient being $0.967(\mathrm{P}<0.001)$ as compared with $0.995(\mathrm{P}<$ $0.001)$ for the alfalfa cited above. Relationships existed between the crude lignin content and the contents of DCP and TDN, and their correlation coefficients were $-0.761(\mathrm{P}<0.01)$ and $-0.786(P<0.01)$, respectively. The crude lignin content was more closely correlated with the TDN content in the alfalfa cited above than in the the Ladino clover in these experiments. This is probably due to the fact that the TDN content for the Ladino clover varied little with the date of harvest as compared with the alfalfa.

It is clear from the data in Table 6 that the crude protein (CP) and the crude lignin (CL) are the prominent constituents for the purpose of predicting DCP and TDN, respectively, and the following equations are given: $\mathrm{DCP}=-4.62+1.003 \mathrm{CP}$ (S.E. \pm 0.87 ) and $\mathrm{TDN}=83.25$ $-1.599 \mathrm{CL}$ (S.E. \pm 2.53 ) where crude protein, crude lignin, DCP and TDN contents are shown in percentage of dry matter.

\section{Summary}

Effects of the time of repeated harvest in regrowth period as well as the stage of maturity in spring on the feeding value of Ladino clover produced in the warmer Setouchi district of Japan have been determined in 1966 and 1967.

1. As the plant matured in spring the contents of crude fiber and crude lignin increased considerably whereas that of crude protein decreased markedly. Moreover, the content of phosphorus also decreased but not very much. The calcium content increased slightly after a decrease in the initial stages. The DCP content declined sharply at a rate of $0.26 \%$ units per day from the early vegetative to the early bloom stage but the TDN content remained almost unchanged.

2. An appreciable difference in the average content of DCP for the first-fourth crops harvested at approximately the early bloom stage was not found between both years but the average TDN content was higher in 1967 than in 1966. The DCP and TDN contents for the fourth crops harvested in the fall of both years showed a tendency of being higher than those of the first to third crops.

3. Crude protein (CP) and crude lignin (CL) are the prominent constituents for the prediction of $\mathrm{DCP}$ and $\mathrm{TDN}$, respectively, and the following equations are given: $\mathrm{DCP}=-4.26$ $+1.003 \mathrm{CP}$ (S.E. \pm 0.87$)$ and $\mathrm{TDN}=83.25-1.599 \mathrm{CL}$ (S.E. \pm 2.53 ).

\section{References}

1) A.O.A.C. (1955) Official Methods of A.O.A.C.: 8 th. Ed. p. 367.

2) Ітон, H. and T. Hatano (1960) The Tohoku Journal of Agricultural Research, 11 (2): $133-146$.

3) Kametaka, M. and S. Haruyama (1954) J. Agr. Chem. Soc. of Japan, 28: 309-314.

4) Miaki, T. (1967) Jap. J. Zootech. Sci., 38: 96-102. 


\section{飼料作物の化学的成分と飼料価值に関する研究}

XIII. 瀬戸内地帯で生産されたラジノクローバーの化学的成分と飼料

価值におよぼす生育段階と刚取回次の影響について

$$
\text { 三 秋 尚 }
$$

(岡山大学農学部)

\begin{abstract}
瀬戸内地带（岡山大学農学部附属農場）で生産された ラジノクローベーの飼料価值におよぼす 1 番刈草の生育 段階々再生草の刚取回次の影蠁について 1966 年々 1967 年の两年にわたって検討した.

1 番刚草において生育がすすもにつれて, 葉量, 粗蛋 白質, リン含量が減少し，粗瀻維と粗りグニン含量が增 加した．カルシウム合量は生育の初期にわずが減少 し，その後開花初期にわずかながら增加の傾向がみられ た. DCP 含量もまた 1 日あたり $0.26 \%$ ゔつ低下した が、TDN 含量法注とんど变化しなかった。
\end{abstract}

開花初期頃に収椤した I〜4 番刈草の飼料成分含量は

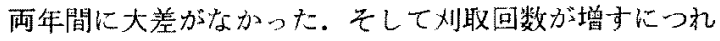

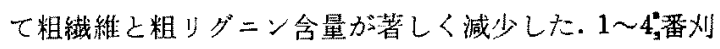
草を含めた両年の平均 DCP 含量は $22.0 \pm 2.5 \%$. TDN 含量は $70.1 \pm 4.3 \%$ ，カルシウム含量は $1.71 \pm 0.16 \%$, リン合量は $0.42 \pm 0.06 \%$ であった。

粗蛋白質 (CP) と粗りグニン (CL) が DCP と TDN 含 量のそれぞれを推定するためのすぐれた成分で次の方程 式を得た。 $\mathrm{DCP}=-4.62+1.003 \mathrm{CP}$ (推定值の標準誤差 0.87 ), $\mathrm{TDN}=83.25-1.599 \mathrm{CL}$ (推定値の標準誤差 $2.53)$, 各成分含量は乾物中の\%で示す。 